\title{
Borlaug Global Rust Initiative provides momentum for wheat rust research
}

\author{
R. A. McIntosh $\cdot$ Z. A. Pretorius
}

Published online: 24 February 2011

(C) Springer Science+Business Media B.V. 2011

The discovery in 1999 in Uganda (Pretorius et al. 2000) of stem rust on wheat varieties with the 1BL.1RS translocation carrying the gene known as Sr31 came as re-awakening, even when it should not have been unexpected. The worldwide deployment of wheat varieties with the translocation probably had an effect of reducing inoculum, resulting in low incidence of the disease over an extended period. Stem rust resistance was only one of a number of advantageous features of the translocation. With acquisition of virulence for $\mathrm{Sr} 31$, race $\mathrm{Ug} 99$ as it became known, was subsequently found in epidemic proportions in Kenya and Ethiopia. Stem rust had not been a significant problem in Kenya for many years prior to 2000 although the region was a historic hotspot for the disease. In Ethiopia, with about $40 \%$ of the area growing durum the situation was different; stem rust continued to be a recurrent problem on durum whereas bread wheat was generally resistant. Subsequent events of rapid mutational changes in Ug99 to attack varieties with $\mathrm{Sr} 24$ and $\mathrm{Sr} 36$, and its further migration to Yemen and Iran, caused major

R. A. McIntosh ( $\square)$

The University of Sydney Plant Breeding Institute

Cobbitty, Private Bag 4011, Narellan,

NSW 2567, Australia

e-mail: robert.mcintosh@sydney.edu.au

\section{Z. A. Pretorius}

Department of Plant Sciences, University of the Free

State, Bloemfontein 9300, South Africa concern and a prediction of the likelihood of further movement to the important grain production areas of the Indian subcontinent and beyond. Previously races of the stripe rust pathogen virulent for $\operatorname{Yr} 9$, also in the same 1BL.1RS translocation, were observed sequentially from equatorial Africa to India suggesting the entire wheat area in Asia may comprise a single epidemiologic zone (Singh et al. 2004, 2008).

Preliminary laboratory and field tests with Ug99 confirmed that it not only had virulence for $\operatorname{Sr} 31$, but it also possessed virulence to other genes deployed in contemporary wheat varieties along with obvious fitness attributes. Most importantly it could cause disease on the widely used variety (mega-variety) Attila and sibs that were being widely grown from Kenya to India and Afghanistan under several different names.

International concern regarding the threat to world wheat production caused by $\mathrm{Ug} 99$ led to the durable rust resistance in wheat project at Cornell University funded by the Bill and Melinda Gates Foundation and establishment of a Global Rust Initiative (later Borlaug Global Rust Initiative, BGRI). The BGRI led by Cornell University, CIMMYT, ICARDA and FAO is supported by many national governments and research centres. Clearly, stem rust is only one of the three rusts that threaten wheat, and currently there is a group of rapidly spreading races of the stripe rust pathogen that is a major threat to production at least as great as Ug99.

One of the objectives of BGRI is to conduct an annual meeting. The first meeting was held at Ciudad 
Obregon, Mexico, in 2009 and the second was in St Petersburg, Russian Federation, in 2010. The proceedings of those meetings can be found on the BGRI website (http://www.globalrust.org). The papers in this special issue are a selection of those presented at the 2010 meeting.

Long term rust control in cereals based on resistance is not a simple matter of finding and exploiting resistance genes-it involves an array of disciplines ranging across pathology, host: pathogen genetics, breeding, cereal chemistry, agronomy, extension and economics, and finally new varieties must be adopted by farmers as they are developed. To meet the likelihood of population changes in the rust pathogens, post-release monitoring of pathogens and considerations of host gene uniformity/diversity are significant ongoing issues.

Wheat breeding for disease control is not complete unless we encompass all aspects of global pathogen variability and epidemiology, resistance discovery and genetic characterization, germplasm development (pre-breeding), and capture of resistance in competitive high yielding, high quality varieties with sufficient adaptability for adoption in agriculture. Our work does not stop there. We then need to address the problems of pathogen variation-both existing and potential, requiring monitoring, anticipation and the possibility of genetic vulnerability created by the widespread adoption of widely adapted mega-varieties or situations where competing breeding organisations are exploiting the same limited set of resistance genes. Finally there is the problem of complacency that comes with widespread adoption of resistance and re-oriented breeding objectives as other problems increase in priority. A major role for BGRI is to keep 'the eye on the ball' with regard to all these aspects. Wheat is the most widely used food crop for mankind and our genetic resources must be shared by all to control our air-borne (sometimes man-borne) fungal foes that seem free to move around the globe. All these issues must therefore be addressed globally to sustain and increase wheat production into the future.

Some of the papers in this special issue are not those we might expect in a journal like Euphytica because they digress into basic biology on the one hand and to infrastructure and farming systems on the other, but all are aimed at '...promoting stability, adaptability and sustainability in agriculture and agro-industries' (Euphytica: Aims and scope).

\section{References}

Pretorius ZA, Singh RP, Wagoire WW, Payne TS (2000) Detection of virulence to wheat stem rust resistance gene Sr31 in Puccinia graminis f. sp. tritici in Uganda. Plant Dis $84: 203$

Singh RP, William HM, Huerta-Espino J, Rosewarne G (2004) Wheat rust in Asia: meeting the challenges with old and new technologies. In: New directions for a diverse planet. Proc 4th Int Crop Sci Cong, http://www.cropscience.org. au./icsc2004/symposia/3/7/141_singhrp.htm. Brisbane, Australia, September 26-October 1, 2004

Singh RP, Hodson DP, Huerta-Espino J, Jin Y, Njau P, Wanyera R, Herrera-Foessel SA, Ward RW (2008) Will stem rust destroy the world's wheat crop? Adv Agron 98: 271-309 